\title{
INCORPORATION OF UNUSUAL OR UNREASONABLE TERMS INTO CONTRACTS: THE RED HAND RULE AND SIGNED DOCUMENTS
}

\author{
SteVe KapNOULLAS* AND BRUCE ClaRKE**
}

[This article analyses case law relating to the red hand rule. In particular, there is an examination of the decision of the High Court in Toll $v$ Alphapharm Pty Ltd. The judgment of the court signals a clear answer as to whether the red hand rule applies to signed documents. In this context, the authors also consider whether section 52 of the Trade Practices Act, and statutory provisions relating to unconscionability, are available to protect consumers against unusual or unreasonable clauses incorporated into signed contracts. Two recent cases involving share trader David Tweed are also analysed.]

\section{INTRODUCTION}

It is trite law that a party attempting to exclude or limit legal liability, by incorporating an exemption clause into an unsigned contract, must take reasonably sufficient steps (at or before the time of contracting) to give notice of the clause to the other party. ${ }^{1}$ The more unreasonable or unusual the clause, the greater the insistence by some judges that the clause be drawn to the attention of the other party in an explicit way, such as being printed in red ink with a red hand pointing to it. The genesis of the so-called red hand rule is to be found in Spurling v Bradshaw Ltd, ${ }^{2}$ where Lord Denning said:

[T] he more unreasonable a clause is, the greater the notice which must be given of it. Some clauses would need to be printed in red ink with a red hand pointing to it before the notice could be held to be sufficient. ${ }^{3}$

\footnotetext{
* Senior Lecturer, Faculty of Business and Enterprise, Swinburne University of Technology.

**Senior Lecturer, Faculty of Business and Enterprise (Hawthorn) \& Faculty of Higher Education (Lilydale), Swinburne University of Technology.

${ }^{1}$ See Parker v South Eastern Railway Co (1877) 2 CPD 416.

2 [1956] 1 WLR 461.

3 [1956] 1 WLR 461, 466.
} 
In an article written some time ago, Elizabeth McDonald expressed the view that the red hand rule does not apply to signed documents, concluding as follows:

[I]t must be remembered that the rule is not one saying that $\mathrm{D}$ cannot incorporate unreasonable clauses; it merely says that special notice will be required to make such a clause part of the contract ... So in the end the rule cannot prevent $\mathrm{D}$ having a very unusual or unreasonable clause in any contract he makes. D can always put the clause in a red box with a red hand pointing to it or even take the situation outside the rule by obtaining P's signature. It follows that the rule does not actually require the redrafting of any standard form contracts provided D is prepared to give greater prominence to the appropriate clauses or obtain P's signature. ${ }^{4}$

The aim of this article is to review the case law relating to the red hand rule, with a view to examining whether the rule applies to signed contracts. In particular, emphasis will be placed on the High Court's recent decision in Toll (FGCT) Pty Ltd v Alphapharm Pty Ltd ${ }^{5}$ (hereinafter referred to as Toll). If the red hand rule does not apply to signed contracts, an issue that must then be considered is whether this creates a deficiency in the law that will need to be addressed by the legislature.

In Toll the High Court had to consider whether exemption and indemnity clauses in a credit application, signed by an agent of the plaintiff, were binding. Although the High Court did not specifically refer to the red hand rule, what the court had to say in its unanimous judgment signals a clear answer to the question whether the red hand rule applies to signed documents.

If the red hand rule has no application to signed documents, the flow on effect is that any attack on the use of unreasonable or unusual clauses in signed contracts will generally have to be based on section 52 of the Trade Practices Act 1974 (Cth) and statutory provisions relating to unconscionability. This article will therefore include a discussion of two recent cases involving National Exchange Pty Ltd, a company controlled by the share trader David Tweed, where reliance was placed on these statutory provisions by the Australian Securities and Investments Commission (ASIC). The first of these cases is significant because the Full Federal Court also made reference to the red hand rule.

\footnotetext{
${ }^{4}$ Elizabeth McDonald, 'The Duty to Give Notice of Unusual Contract Terms' (1988) Journal of Business Law 375, 385.

${ }^{5}$ (2004) 211 ALR 342.
} 


\section{THE RED HAND RULE}

In Spurling v Bradshaw, ${ }^{6}$ referred to above, the court did not need to consider the red hand rule in detail because of past dealings between the parties and the finding that the clause in question was not unreasonable. Greater attention was placed on the rule in Thornton $v$ Shoe Lane Parking Ltd ${ }^{7}$ where Lord Denning MR dealt with a clause exempting a car park proprietor from liability for personal injury. In the course of his judgment his Lordship said:

I do not pause to enquire whether the exempting condition is void for unreasonableness. All I say is that it is so wide and so destructive of rights that the court should not hold any man bound by it unless it is drawn to his attention in the most explicit way. It is an instance of what I had in mind in $J$ Spurling v. Bradshaw (1956) 1 WLR 461, 466. In order to give sufficient notice, it would need to be printed in red ink with a red hand pointing to it, or something equally startling. ${ }^{8}$

The English Court of Appeal undertook further consideration of the red hand rule in Interfoto Picture Library $v$ Stiletto Visual Programmes Ltd. ${ }^{9}$ The facts of the Interfoto case are reasonably straightforward. The appellant was an advertising agency that required photographs for a presentation to a client. The respondent ran a transparency library. The appellant telephoned the respondent, with whom it had not previously dealt, and enquired whether it had any suitable photographs. The respondent forwarded 47 transparencies, packed in a bag, together with a delivery note.

The delivery note specified the date of return as being fourteen days after the date of dispatch, which was marked as 5 March 1984. At the bottom of the note was a list of nine conditions, one of which (Condition 2) provided for the return of all transparencies within fourteen days, with a holding fee of £5 payable per transparency for each late day, plus VAT. The appellant put the transparencies aside and forgot to return them until 2 April. The respondent claimed the sum of $\$ 3783.50$, in accordance with condition 2 of the delivery note, for retention of the transparencies from 19 March to 2 April.

\footnotetext{
${ }^{6}$ [1956] 1 WLR 461.

${ }^{7}$ (1971) 2 QB 163.

8 (1971) 2 QB 163, 170.

9 (1988) 1 All ER 348. See analysis in Steve Kapnoullas and Bruce Clarke, 'Fine Print in Contracts: From "Invisible Ink" Cases to "Red Ink" Rules' (1993) 19 Melbourne University Law Review 92.
} 
In the lower court, evidence was given that most photographic libraries charged less than $£ 3.50$ per week for retention of transparencies. Surprisingly, it was not argued that condition 2 constituted a penalty. ${ }^{10}$ Rather, the focus was on whether it formed part of the contract between the parties. The trial judge found that it did and entered judgment for the respondent. His Honour's decision on this point was reversed by the Court of Appeal.

Although this was not a case involving exclusion clauses, their Lordships hearing the appeal drew heavily on case law in that area, particularly Parker $v$ South Eastern Railway Company ${ }^{11}$ and Thornton v Shoe Lane Parking Ltd. ${ }^{12}$ As the delivery note was an unsigned document, the question arose as to whether reasonable notice had been given in relation to condition 2 .

In the Interfoto case, Bingham LJ followed on Lord Denning's approach in Thornton's case, holding that the appellant should have realised that the delivery note contained contractual conditions, but only those which one might usually or reasonably expect. The critical question was whether the respondent could be said fairly and reasonably to have brought condition 2 to the notice of the appellant. His Lordship concluded that the appellant was relieved of liability not because it had failed to read the conditions, but because the respondent did not do what was necessary to draw the unreasonable and extortionate clause to the appellant's attention. Similarly, Dillon LJ said:

It is, in my judgment, a logical development of the common law into modern conditions that it should be held, as it was in Thornton v. Shoe Lane Parking $L t d$, that, if one condition in a set of printed conditions is particularly onerous or unusual, the party seeking to enforce it must show that that particular condition was fairly brought to the attention of the other party. ${ }^{13}$

The appellant's appeal was accordingly allowed, although the appellant was ordered to pay $\$ 3.50$ per week per transparency on a quantum meruit basis for retention of the transparencies beyond a reasonable period.

${ }^{10}$ (1988) 1 All ER 348, 358 (Bingham L.J): 'In reaching the conclusion I have expressed I would not wish to be taken as deciding that condition 2 was not challengeable as a disguised penalty clause. This point was not argued before the judge nor raised in the notice of appeal. It was accordingly not argued before us. I have accordingly felt bound to assume, somewhat reluctantly, that condition 2 would be enforceable if fully and fairly brought to the defendants' attention.'

${ }^{11}$ (1877) 2 CPD 416.

${ }_{13}^{12}$ (1971) 2 QB 163.

${ }^{13}$ (1988) 1 All ER 348, 358. 
In Australia, in MacRobertson Miller Airline Services $v$ Commissioner of State Taxation (WA), ${ }^{14}$ Jacobs $\mathrm{J}$ suggested that if an unreasonable clause is included in terms (in this case printed on an unsigned airline ticket) that are not read, and are not likely to be read, then there is no acceptance of that condition. Subsequently, in the High Court case of Oceanic Sun Line Special Shipping Company Inc v Fay, ${ }^{15}$ Brennan J, after referring to Thornton's case, said 'In differing circumstances, different steps may be needed to bring an exemption clause to a passenger's notice, especially if the clause is an unusual one. ${ }^{16}$

However, it should be emphasised that earlier Brennan J also said:

If a passenger signs and thereby binds himself to the terms of a contract of carriage containing a clause exempting the carrier from liability for loss arising out of the carriage, it is immaterial that the passenger did not trouble to discover the contents of the contract. ${ }^{17}$

It appears clear from the above that his Honour was drawing a distinction between signed and unsigned documents, and that the rules relating to reasonable notice, and the red hand rule, do not apply to signed documents.

In Victoria, the red hand rule was considered by the Court of Appeal in Le Mans Grand Prix Circuits Pty Ltd v Iliadis ${ }^{18}$ (Le Mans). Iliadis attended a promotional function at the defendant's go-kart track. He was asked to sign a form headed 'TO HELP US WITH OUR ADVERTISING'. Iliadis gave evidence that he signed the form believing it allowed him to drive a faster vehicle, and that the defendant was using it for marketing purposes. The document contained an exemption clause relieving the defendant from liability for personal injury. Iliadis was injured owing to the defendant's negligence and sued.

The focus of the majority judgment, delivered by Tadgell JA (with whom Winneke $\mathrm{P}$ agreed), was on whether the document signed by the plaintiff was contractual, or alternatively if the parties were in a contractual relationship. In

${ }^{14}$ (1975) 133 CLR 125, 142.

${ }^{15}$ (1988) 165 CLR 197.

${ }^{16}$ (1988) 165 CLR 197, 228.

${ }^{17}$ (1988) 165 CLR 197, 228.

${ }^{18}$ (1998) 4 VR 661. See a full analysis in Bruce Clarke and Steve Kapnoullas, 'When is a Signed Document Contractual? - Taking the "Fun" out of the "Funfair" (2001) 1(1) Queensland University of Technology Law Journal 39. 
the course of argument, however, it appears that the defendant's counsel conceded that contractual documents containing 'an onerous exemptive provision must be brought to the notice of the party against whom they are enforced. ${ }^{, 19}$

Batt JA, in his dissenting judgement, was in no doubt that the rule in $L$ 'Estrange $v$ Graucob ${ }^{20}$ applied to the facts of this case, and that knowledge of the contents of a document will be presumed where it is signed. It is only where a contractual document is not signed that a different rule applies, viz that the party relying on the document's terms must establish reasonable or sufficient notice. In the judgment of Batt JA the Interfoto case did not apply because the document in that case was unsigned. Put simply, the requirement of reasonable notice, and therefore the red hand rule, does not apply to signed documents. $^{21}$

As noted in the introduction to this article, recently the red hand rule was briefly referred to by the Full Federal Court in National Exchange Pty Ltd $v$ ASIC (National Exchange No 1). ${ }^{22}$ David Tweed, a share trader, through his company National Exchange Pty Ltd, specialises in making off-market offers to buy shares. He has estimated that he has made $\$ 10$ million by buying shares below their stockmarket price. ${ }^{23}$

In 2003 ASIC passed a requirement that off-market share offers must disclose the market price of the shares. National Exchange offered to buy shares valued at $\$ 1.93$ for $\$ 2.00$, which appeared to be seven cents above the market value. However, a clause in the fine print of the offer document provided for payment over fifteen annual instalments. One potential seller was nearly eighty years old, and it was doubtful therefore whether she would have lived long enough to receive payment in full.

ASIC sought an order under section 1041 of the Corporations Act 2001. Section 1041 states:

\footnotetext{
${ }^{19}$ (1998) 4 VR 661, 667.

${ }^{20}$ (1934) 2 KB 394.

${ }^{21}$ (1988) 4 VR 661, 673-674. His Honour said "Signature and reasonable notice are to a large extent counterparts in the respective cases of signed and unsigned documents: signing affords the person who signs the opportunity to become aware of the contents of the document."

22 (2004) FCAFC 90.

23 Leonie Wood, 'Share scammer rakes in $\$ 10 \mathrm{~m}$ from four deals' The Age (Melbourne) 7 December 2004.
} 
A person must not engage in conduct, in relation to a financial product or a financial service, that is misleading or deceptive, or is likely to mislead or deceive.

This section is virtually identical to section 52 of the Trade Practices Act.

In the course of their judgments, their Honours Jacobson and Bennett JJ, immediately before referring to Spurling $v$ Bradshaw, said:

The representation made in the table is that the shareholders will receive in cash in full on acceptance a premium of 7 cents over the closing price. The true position is that accepting shareholders make an interest free loan of the purchase price to the appellant over a period of 15 years. To describe it as a cheeky offer would be to understate the full import of the document.

Where the disparity between the primary statement and the true position is great it is necessary for the maker of the statement to draw the attention of the reader to the true position in the clearest possible way. ${ }^{24}$

Although it has to be said that the Full Federal Court was more concerned with determining whether the offer document itself was misleading, ${ }^{25}$ this dictum, and more particularly the decision in Le Mans, constitute the little case law in Australia that suggests the red hand rule may have application to signed documents. This meant there was a degree of uncertainty in the law, to the extent that it required the attention of the High Court in Toll.

\section{TOLL}

\section{A The Facts of Toll}

The facts of Toll are complicated, but it is only necessary to refer to those facts relevant to the essential issue raised by this article. Richard Thomson Pty Ltd (Thomson), acting as agent ${ }^{26}$ for Alphapharm, arranged for Toll (formerly known as Finemores) to transport a large quantity of flu vaccine. The vaccine was stored and transported by Toll at below the suggested temperature, damaging the vaccine and resulting in a loss of $\$ 683,061$.

${ }^{24}$ (2004) FCAFC 90, [54]-[55].

25 The offer document was accompanied with a standard share transfer form, which had to be signed and returned by shareholders wishing to accept the offer.

${ }^{26}$ One of the issues the court had to decide in this case was whether Thomson had acted as agent for Alphapharm. This aspect of the case is not important to the issue raised by this article. However, the High Court did find that Thomson, through its representative Mr. Gardiner-Garden, did have authority to bind Alphapharm. 
The carrier, Toll, claimed that it was not liable because the agreement between the parties included a clause (condition 6) exempting it from liability for 'theft, misdelivery, delay in delivery, loss, damage or destruction, by any cause whatsoever' including breach of contract or negligence. Another clause (condition 8) contained an indemnity from Thomson, in favour of Toll, in relation to any claim made by Associates of Thomson. 'Associates' was defined to mean:

(i) the owner, sender or receiver of the goods;

(ii) a person having an interest in the goods;

(iii) the Customer's principal; and

(iv) any agent, representative, employee or sub-contractor of the Customer or those persons.

The clauses in question were printed on the back of a document signed by Thomson's representative, Mr. Gardiner-Garden. The document was headed 'Application for Credit'. Prior to signing the credit application, Thomson had received a quote by facsimile, which included the following statement:

[I]t would be very much appreciated if you would complete the Credit Application and sign the Freight Rate Schedule accepting our Rates and Conditions and fax back to our office at your earliest convenience.

On behalf of Thomson, Mr. Gardiner-Garden subsequently signed the Application for Credit. Immediately above the place where he signed appeared the words 'Please read 'conditions of contract (overleaf) prior to signing'.

Mr. Gardiner-Garden gave evidence that he did not read the conditions of contract. There was no suggestion of misrepresentation, nor was there anything to prevent Mr. Gardiner-Garden from reading the document. The type of exemption and indemnity clauses included in the document were commonly used in the refrigerated transport industry. However, Mr. GardinerGarden gave evidence that he would not have signed the Application for Credit had he been aware of the clauses in question.

The claim for damages against Toll was primarily based on an allegation of negligence (as a bailee), although a claim was also brought under section 52 of the Trade Practices Act. 


\section{B Toll in the Lower Courts}

The trial judge, in the District Court of New South Wales, was of the view that to determine the outcome of this dispute the correct test to apply was whether the defendant gave reasonable notice of the 'Conditions of Contract'. The trial judge said:

$\mathrm{Mr}$ Garden had already read a document containing rates and conditions. He was then presented with another document which on its face related to matters relevant to his company's creditworthiness. All that was done to give him notice was the single sentence above the space provided for his signature which read "Please read 'conditions of contract' (overleaf) prior to signing." Had he noticed that sentence, he would have been quite justified in assuming that overleaf there were conditions relating to the terms upon which credit would be extended to his company. Conditions about cartage and storage had been set out in the previous document. There was nothing in the Application for Credit document itself, in the surrounding circumstances or in anything that Finemores [Toll] had said or done that should have alerted him to the fact that the document contained conditions which so radically affected the contract. ${ }^{27}$

All three judges of the New South Wales Court of Appeal ${ }^{28}$ (Sheller JA, Young CJ in Eq and Bryson J.) agreed that the critical question was that of reasonable notice. Although no specific reference was made to the red hand rule, all judges concluded that reasonable notice had not been given, because the clauses appeared in a document headed 'Application for Credit', where one would not expect to find such conditions. Their Honours rejected the argument by counsel for Toll that there was no authority requiring reasonable notice where a contract has been signed, even where the contract contains terms extraneous to the subject matter of the document signed.

Young CJ in Eq, although briefly noting some academic disquiet about L'Estrange $v$ Graucob, stated that 'it is a very useful principle properly understood and should continue to be applied. ${ }^{29}$ However, his Honour went on to find that reasonable notice had not been given of the clauses in question.

Bryson $\mathrm{J}$ also reached the same conclusion, but his Honour's reasoning was slightly different. Signature is usually a very strong indication of an intention

${ }^{27}$ See (2004) 211 ALR 342 [58] (emphasis added).

${ }^{28}$ (2003) NSWCA 75.

${ }^{29}$ (2003) NSWCA 75, [69]. 
to be bound, but does not exclude consideration of 'facts and circumstances which may show it was not. ${ }^{30}$ His Honour concluded:

The conditions, particularly Condition 8 , are in no way what one would reasonably expect or suppose would be found incorporated in an Application for Credit...[A]ny reasonable person would be astonished to find that he was asked, as a condition of being given 14 days' credit, to indemnify his supplier from claims arising out of the transaction; unless it was pointed out to him he would never think it might be there. ${ }^{31}$

Commenting on this case in a recent text on contract law ${ }^{32}$ the authors conclude:

The decision of the New South Wales Court of Appeal does not sit comfortably with the rule in L'Estrange $v$ Graucob as it is traditionally applied, that if a document is contractual in nature, the signer will be bound by its terms. ${ }^{33}$

After acknowledging that Mr. Gardiner-Garden would have no reason to expect the Application for Credit to contain terms relevant to the transport contract the authors continue:

Further modification of the rule in L'Estrange $v$ Graucob may well be justified so that a person is not bound by terms that he or she would not normally expect to find in a contract of that kind simply because it has been signed. $^{34}$

This appears to be an indirect acceptance that a party should not be bound by unreasonable or unusual terms even if a contract has been signed; in other words, an acknowledgment that the red hand rule can have application to signed contracts. ${ }^{35}$ The above statement was made before the High Court delivered its judgment in Toll, which it is now appropriate to examine. Would the High Court be prepared to accept further exceptions to L'Estrange $v$ Graucob?

\footnotetext{
${ }^{30}$ (2003) NSWCA 75, [105].

${ }^{31}$ (2003) NSWCA 7 [138].

${ }^{32}$ Lindy Wilmott, Sharon Christensen and Des Butler, Contract Law (2nd ed, 2005).

${ }^{33}$ Ibid 224.

${ }^{34}$ Ibid.

${ }^{35}$ The authors also state that, 'the general rule in L'Estrange $v$ Graucob would continue to apply, but additional steps must be taken by a person seeking to rely on the term or terms if they would not ordinarily be found in a contract of that type.'
} 


\section{Toll in the High Court}

In the High Court's unanimous judgment in favour of Toll, the rule in L'Estrange v Graucob was strictly applied. The Court referred to Wilton $v$ Farnworth, ${ }^{36}$ where Latham C.J emphasised that any weakening of the principles relating to the binding effect of signature would lead to chaos in every day business transactions. ${ }^{37}$

The High Court further observed that legal instruments of various kinds take their efficacy from signature or execution, and that people who have not read and understood all their terms often sign such instruments. Such people are nevertheless committed to those terms by the act of signature or execution. It is that commitment which enables third parties to assume the legal efficacy of the instrument. 'To undermine that assumption would cause serious mischief. ${ }^{38}$

In reaching their decision in Toll, the judges in the courts below failed to adequately distinguish between signed and unsigned documents. The High Court referred to the judgments of Mellish LJ in Parker $v$ South Eastern Railway Company ${ }^{39}$ and Brennan J in Oceanic Sun Ltd v Fay, ${ }^{40}$ judgments which drew a clear distinction between signed and unsigned documents. The High Court emphasised that:

The general rule, which applies in the present case, is that where there is no suggested vitiating element, and no claim for equitable or statutory relief, a person who signs a document which is known by that person to contain contractual terms, and to affect legal relations, is bound by those terms, and it is immaterial that the person has not read the document. L' Estrange $v$ Graucob explicitly rejected an attempt to import the principles relating to ticket cases into the area of signed contracts. ${ }^{41}$

The document that Mr. Gardiner-Garden signed in Toll was clearly contractual and intended to affect the legal relations between the parties. The court distinguished some of the case law relied on by the plaintiff in the court below, where signature was obtained on non-contractual documents.

${ }^{36}$ (1975) 132 CLR 646, 649.

${ }^{37}$ (2004) 211 ALR 342, [45].

${ }^{38}$ (2004) 211 ALR 342, [47].

39 (1877) 2 CPD 416.

40 (1988) 165 CLR 197.

${ }^{41}$ (2004) 211 ALR 342, [57]. 
The High Court was undoubtedly influenced by the fact that the parties in Toll operated in a commercial context. In addition, Alphapharm had insurance covering the damage to the vaccine. There was no suggestion of misrepresentation and Mr. Gardiner-Garden had every opportunity to read the document, but did not take the trouble to do so. The court was unimpressed by Mr. Gardiner-Garden's assertion, in evidence, that he would not have signed the Application for Credit had he known that it contained exemption and indemnity clauses. ${ }^{42}$ The court made it clear, that in cases such as this, the objective approach is adopted to determine the intention of the parties. ${ }^{43}$

Le Mans, previously referred to in this article, was distinguished by the High Court on the basis of the defendant's somewhat surprising concession in that case that reasonable steps must be taken to bring onerous provisions in a contractual document to the notice of the party against whom they are to be enforced. ${ }^{44}$ The court nevertheless seemed to suggest that the outcome of Le Mans could be supported on the basis of a misrepresentation as to the nature of the document signed.

Intriguingly, the High Court, whilst affirming that the exceptions to L'Estrange v Graucob are to be kept within narrow parameters, ${ }^{45}$ went on to say:

There are circumstances in which it is material to ask whether a person who has signed a document was given reasonable notice of what was in it. Cases where misrepresentation is alleged, or where mistake is claimed, provide examples. No one suggests that the fact that a document has been signed is for all purposes conclusive as to its legal effect. ${ }^{46}$

Further on in its judgment the court also remarked that there 'may be cases where the circumstances in which a document is presented for signature, or the presence in it of unusual terms, could involve misrepresentation. ${ }^{47}$

\footnotetext{
${ }^{42}$ (2004) 211 ALR 342, [35].

${ }^{43}$ The issue as to what extrinsic evidence is available in such situations is explored elsewhere: see Elisabeth Peden and John W Carter, 'Incorporation of Terms by Signature: L’Estrange Rules!' (2005) 21 Journal of Contract Law 96.

${ }^{44}$ (2004) 211 ALR 342, [66].

${ }^{45}$ See reference to Petelin $v$ Cullen (1975) 132 CLR 355 at (2004) 211 ALR 342, [46].

${ }^{46}$ (2004) 211 ALR 342, [54].

${ }^{47}$ (2004) 211 ALR 342, [63]. The court continued by saying, 'There could also be circumstances in which one party would not reasonably understand another party's signature to a document as a manifestation of intent to enter into legal relations, or of assent to its terms.'
} 
This dictum is equivocal, and with respect, somewhat confusing. As Peden and Carter argue, 'there has never been any requirement of reasonableness when holding another bound to a signed contract. ${ }^{48}$

The High Court gives little guidance as to what might constitute unusual terms. One can only speculate what their Honour's had in mind. For example, in National Exchange No 1, previously referred to, assume a shareholder was to sign the offer document forwarded to him or her. It will be re-called that the document contained an unusual, and arguably unreasonable, clause providing for payment over fifteen years. Is this the type of circumstance the High Court had in mind?

\section{Analysis}

It should be emphasised that in Toll there was no direct reference to the red hand rule. Nevertheless, the core of the plaintiff's argument was that one would not expect to find exclusionary or indemnity clauses in an Application for Credit. As the High Court observed:

It appears from the reasoning of the primary judge and the Court of Appeal that the proposition [requiring reasonable notice] was given narrower focus, and was limited to exclusion clauses, or, perhaps, exclusion clauses which are regarded by a court as unusual and onerous. ${ }^{49}$

By rejecting this argument the judgment of the High Court therefore supports the view expressed by McDonald, referred to in the introduction to this article, that the red hand rule does not apply to signed documents.

The High Court considered that the exclusion and indemnity clauses in the document signed by $\mathrm{Mr}$ Gardiner-Garden on behalf of Thomson were commonly employed in the refrigerated transport industry. With respect, even if the court's conclusion on this point is accepted, it could just as easily be argued that Thomson would have no reason to expect terms relevant to a transport contract in an Application for Credit. ${ }^{50}$ To put it another way, the

\footnotetext{
${ }^{48}$ See Peden and Carter, above n 43, 102.

${ }^{49}$ [2004] 211 ALR 342, [54] (emphasis added).

${ }^{50}$ See Wilmott, Christensen and Butler, above n 32, 224. See also Peden and Carter, above $\mathrm{n}$ 43, who state at 104: 'Although it was clearly appropriate for Alphapharm (acting through Richard Thomson) to assume that there were additional terms in the Application, it would not have been unreasonable to assume that these related to the terms of credit, not to exclusion of liability.'
} 
'expectations of honest businessmen', to coin a phrase used by Lord Justice Steyn, ${ }^{51}$ would be that a credit contract would normally contain terms relevant to that type of contract, and not terms which were completely alien in nature. In the same context, we believe that the High Court's criticism of Le Mans is not warranted, as a reasonable person would not expect to find exclusionary provisions in a document headed 'TO HELP US WITH OUR ADVERTISING'.

Another aspect deserving comment is the High Court's emphasis on the commercial nature of the transaction. The court noted that:

Each of the ... parties to the case is a substantial commercial organisation, capable of looking after its own interests. This hardly seems an auspicious setting for an argument that a party who signs a contractual document is not bound by its terms because its representative did not read the document. ${ }^{52}$

Together with its decision in ACCC $v$ Berbatis Holdings Pty $L t d^{53}$ and more recently in Butcher $v$ Lachlan Elder Realty ${ }^{54}$, the High Court is showing a concern for upholding commercial contracts. As Peden and Carter conclude, 'the decision illustrates that when not distracted by equity the High Court will adopt a 'hands off' approach to commercial contracts under which orthodoxy rules. $^{55}$

\footnotetext{
${ }^{51}$ Lord Johan Steyn, 'Contract Law: Fulfilling the Reasonable Expectations of Honest Men’ (1997) 113 Law Quarterly Review 433.

${ }_{53}^{52}$ (2004) 211 ALR 342, [29].

53 (2003) 197 ALR 153. At 157 Gleeson C J said 'In the present case, there was neither a special disadvantage on the part of the lessees, nor unconscientious conduct on the part of the lessors. All the people involved in the transaction were business people, concerned to advance or protect their own interest.' See the discussion by Rick Bigwood, 'Curbing Unconscionability: Berbatis in the High Court of Australia' (2004) 28 Melbourne University .Law Review 203 and Liam Brown, 'The Impact of Section 51AC of the Trade Practices Act 1974 (Cth) on Commercial Certainty' (2004) 28 Melbourne University Law Review 589.

54 (2004) ALJR 308. Analysed by Dr Warren Pengilley, 'Misleading or deceptive conduct considered by the High Court. Does Butcher's case indicate a new judicial conservatism?' (2005) 12 Competition and Consumer Law Journal 314.

${ }^{55}$ See Peden and Carter, above n 43, at 105 . See also Peter Lovell and John Nunns, 'Business to Business Contracts in the High Court: A "Hands Off" Approach?'Conference Papers, Television Education Network (Melbourne - August 2005).
} 
In refusing to create further exceptions to L'Estrange v Graucob, the High Court made the observation that consumers, in particular, were sufficiently protected by statutory provisions designed to ameliorate the strictness of the rule. This observation requires further consideration.

\section{THE IMPACT OF STATUTORY LAW ON THE RULE IN L'ESTRANGE V GRAUCOB ${ }^{56}$}

The extent to which s 52 of the Trade Practices Act can be utilised in cases involving signed contracts was not reviewed by the High Court in Toll. The plaintiff in Toll did initially allege that the conduct of the defendant was misleading and deceptive in breach of s 52 , but the trial judge dismissed the allegation, and no appeal against that decision was made. Whilst the High Court in Toll acknowledged that statutory relief sometimes ameliorates the hardship caused by the strict application of legal principle to contractual relations, it put the availability of such relief into context by observing 'there is no reason to depart from principle, and every reason to adhere to it, in cases where such legislation does not apply, or is not invoked. ${ }^{57}$

Section 52 has been successfully utilised in relation to commercial contracts that contained provisions that contradicted verbal representations made by defendants. ${ }^{58}$ The statutory remedy is independent of the contract. But it must be remembered that a claim under s 52 rests on establishing misleading or deceptive conduct. In Toll there was no evidence that the plaintiff was tricked or misled into signing the Application for Credit, so consequently, as previously mentioned, the trial judge dismissed the claim based on s 52 .

\footnotetext{
${ }^{56}$ It should not be forgotten that other provisions in the Trade Practices Act limit the use of exclusion clauses in consumer type contracts. Furthermore, the Contracts Review Act 1980 (NSW) may also operate to protect consumers. The recent introduction of Part 2B - 'Unfair Terms in Consumer Contracts' (ss 32U - 32ZD) into the Victorian Fair Trading Act 1999 is also designed to strengthen the rights of consumers with regard to unfair contracts: see James Catlin, 'Consumers benefit from transparency' (2004) (Feb - March) Law Institute Journal 54. Finally, reference should be made to section 37 of the Insurance Contracts Act 1984 (Cth), which deals with notification of unusual terms in contracts of insurance. This is, in effect, a statutory recognition of the red hand rule in the area of insurance.

${ }^{57}$ [2004] 211 ALR 342, [48] (High Court of Australia 2004).

${ }^{58}$ See for example Dibble v Aidan Nominees Pty Ltd (1986) ATPR 40-693 and Lezam Pty Ltd v Seabridge Australia Pty Ltd (1992) 107 ALR 291.
} 
The intrusion of s 52 into the field of contract law has been subject to criticism, ${ }^{59}$ but as National Exchange No 1 shows, there is scope to apply the section in limited circumstances. In National Exchange No 1, as observed earlier in this article, the court relied on a provision in the Corporations Act that is the statutory equivalent to s 52 of the Trade Practices Act.

It will be recalled that in National Exchange No 1 the share offer document contained an unusual, and arguably unreasonable, clause providing for payment of the consideration over 15 years. The Full Federal Court found that the document was misleading or deceptive, even though it contained nothing that was literally false. Insufficient prominence had been given to the terms of payment in the offer document, leaving some shareholders, especially those who were less than careful readers, with a misleading impression as to the cash amount they were to receive upon acceptance. When seeking leave to appeal to the High Court, National Exchange argued that it should not be liable for misleading or deceptive conduct if the shareholders were misled only because they failed to read the document given to them, when the document was expressed in relatively clear and unambiguous terms. The High Court rejected the submission and refused special leave to appeal from that decision. $^{60}$

By way of contrast, more recently in ASIC $v$ National Exchange Pty Ltd ${ }^{61}$ (National Exchange No 2) the Full Federal Court has held that a statutory equivalent to s 52 was not infringed. The facts can be summarised briefly. National Exchange made an off-market offer to members of Aevum, a demutualised company. The offer was to buy at 35 cents a share. The offer document contained a statement advising that National Exchange considered a fair value of each share to be in the range of $\$ 0.90$ to $\$ 1.29$. Notwithstanding this, National Exchange's offer to purchase at $\$ 0.35$ was accepted by 257 shareholders. When the shares were listed for trading they opened at $\$ 1.54$ per share, which was 4.4 times the price offered by National Exchange.

\footnotetext{
${ }^{59}$ Diane Skapinker and John W Carter, 'Breach of Contract and Misleading Conduct in Australia' (1997) 113 Law Quarterly Review 294. But see the retort by Jason Cornwall-Jones, 'Breach of Contract and Misleading Conduct: A Storm in the Teacup?' (2000) 24 Melbourne University Law Review 249 and also Dr Vivien Goldwasser and Tony Ciro, 'Standards of Behaviour in Commercial Contracting' (2002) 30 Australian Business Law .Review 369 and Russell Miller, 'From acorn to oak tree: The spreading branches of s 52 of the Australian Trade Practices Act 1974' (2005) 79 Australian Law Journal 4.

${ }^{60}$ National Exchange Pty Ltd v ASIC [2004] HCATrans 557.

${ }^{61}$ [2005] FCAFC 226.
} 
The main issue in the case was whether National Exchange had engaged in misleading conduct, or alternatively unconscionable conduct, pursuant to statute law. As to the first ground the Full Court held that the clear language of the offer document meant that there was no misrepresentation or deception. This was in spite of the fact that the document was cast in such a way that the critical information as to the fair estimate of the value of the shares was not contained on the front page in close proximity to the consideration for the offer - it was on the reverse page - and nor was it linked to the consideration. The court concluded that the document did not exhort or advise offerees to accept the offer, or represent that the price was fair. Rather, it urged shareholders to obtain their own share valuation and to read the entire document. The document was a short one and was not in legalistic terms. National Exchange clearly stated its estimate of a fair value range for the shares.

It is difficult to reconcile the decision of the Full Federal Court with regard to s 52 in this case with the decision reached in National Exchange No 1. To provide for payment over 15 years was held to be misleading in National Exchange No 1, whereas an offer to buy shares at a gross undervalue in National Exchange No 2 was not; even though a fair estimate of their value was tucked away on the back of the offer document.

It should be noted, however, that the court did conclude that National Exchange, by targeting vulnerable shareholders 'ripe for exploitation', had engaged in unconscionable conduct under s 12CB (and 12CC) of the Australian Securities and Investment Commission Act 2001 (Cth), which broadly equates with s $51 \mathrm{AB}$ (and s 51AC) of the Trade Practices Act. Section $12 \mathrm{CB}$ is concerned with unconscionable conduct in relation to the supply of services to consumers. However, the court went on to hold, inter alia, that the acceptance of a share offer 'cannot be said' to be a financial service 'of a kind ordinarily acquired for personal, domestic or household use', and therefore fell outside the parameters of s $12 \mathrm{CB} .{ }^{62}$ This finding was

${ }^{62}$ [2005] FCAFC 226, [49].

Note: Section 12CC did not apply in this case because it is designed to protect small businesses, as is s $51 \mathrm{AC}$ of the Trade Practices Act. In reaching its decision in this case the court referred to an article by Gail Pearson, 'The ambit of unconscionable conduct in relation to financial services' (2005) 23 Company and Securities Law Journal 105.

Note also: The court concluded that National Exchange had failed to comply with the provisions of the Corporations Act 2001 (Cth) requiring its offer to be held open for one month - offerees in this case had to accept in 7 days. 
reached with little analysis of the issue. In this day and age, when 'Mum and Dad' investors are commonly managing their own share portfolios, it is the view of the authors that this matter deserved more careful consideration. ${ }^{63}$

As a result of this decision the legislature may need to consider amending $\mathrm{s}$ $51 \mathrm{AB}$ of the Trade Practices Act (and similar statutory provisions in other pieces of legislation) to broaden the definition of 'consumer'. One possibility is to adopt the method used in $\mathrm{s} 4 \mathrm{~B}$ of the Act, where transactions, unless specifically excluded, are deemed to be 'consumer' transactions if the price of the goods or services does not exceed a prescribed amount (presently $\$ 40,000) .^{64}$

In summary, Toll has shown that there is little scope to apply the red hand rule to signed documents. However, the two National Exchange cases also show that s 52 of the Trade Practices Act, and statutory provisions relating to unconscionability, are sometimes available to 'consumers' where unreasonable, unusual or onerous clauses are incorporated into a contract.

\section{CONCLUSION}

The signed document rule laid down by L'Estrange $v$ Graucob has been subject to criticism. Lord Denning, who successfully argued for the defendant in L' Estrange $v$ Graucob, went on to say subsequently that this case, together with Thompson $v$ London, Midland and Scottish Railway Co ${ }^{65}$ represented a 'bleak winter' for the law of contract. ${ }^{66}$ Ironically, Stephen Gageler SC, who appeared for the defendant in Toll, in a joint article written with Sir Anthony Mason some years earlier, made reference to the principle laid down by $L$ 'Estrange $v$ Graucob and noted 'that the requirements of fairness and justice may call for its re-examination. ${ }^{, 67}$

\footnotetext{
${ }^{63}$ See Bruce Clarke and Steve Kapnoullas, 'The Definition of 'Consumer' in the Trade Practices Act: A Guide for the Perplexed'(1993) 1 Current Contract Law 10

${ }^{64}$ If the price exceeds the prescribed amount, the transaction will still be a 'consumer' transaction if the goods or services are of a kind ordinarily acquired for personal, domestic or household use or consumption.

${ }_{65}^{65}(1930) 1 \mathrm{~KB} 41$.

${ }^{66}$ In George Mitchell (Chesterhall) v Finney Lock Seeds Ltd (1983) 1 QB 284, 296.

${ }^{67}$ Sir Anthony Mason and Stephen J Gageler, 'The Contract' in PD Finn (ed), Essays in Contract (3rd ed, 1987) 12.
} 
Similarly, one American author, M I Meyerson, ${ }^{68}$ has remarked:

Courts moralistically preached that if a person failed to read the contract 'he cannot set up his own carelessness and indolence as a defense...' [T]his classical theory has no basis in either reality or justice. ${ }^{69}$

Some United States courts have developed a doctrine of unfair surprise to counter the use of unreasonable and unusual clauses 'hidden in a maze of fine print'. ${ }^{70}$ However, in Toll the High Court considered the distinction between signed and unsigned documents to be critical in the context of incorporation. ${ }^{71}$ So far as the red hand rule is concerned it appears to be clear that there is little room to argue that it applies to signed contracts. The High Court in Toll has signalled that, apart from statute law, the exceptions to L'Estrange $v$ Graucob are to be narrowly confined to areas such as misrepresentation, mistake, non est factum and unconscionability.

In refusing to create further exceptions to L'Estrange $v$ Graucob, the High Court observed that consumers, in particular, are sufficiently protected by statutory provisions designed to ameliorate the strictness of the rule. This is debatable, given the recent decision in National Exchange No 2. We would suggest that there is a need for the legislature to step in and strengthen the protection offered by statutory regimes. The decisions in Toll and National Exchange No 2 leave the 'consumer' inadequately protected against those who would wish to take advantage of the credulity of some consumers faced with a decision that involves reading and signing a contractual document. The fact that David Tweed, through his company National Exchange, has made an estimated $\$ 10$ million from offers to buy shares well below their stockmarket price provides ample evidence that many consumers do not take the trouble to read the fine print in contracts before signing them.

${ }^{68}$ Michael I Meyerson, 'The Reunification of Contract Law: The Objective Theory of Consumer Form Contracts' (1993) 47 University of Miami Law Review 1263, 1273.

${ }^{69}$ See also Robert A Hillman and Jeffrey J Rachlinski, 'Standard From Contracting in the Electronic Age' (2002) 77 New York University Law Review 429, who argue that many consumers are not likely to take the trouble to read terms and conditions contained in contracts entered into on the Internet. See also the criticism by John R Spencer, 'Signature, Consent, and the Rule in L' Estrange v Graucob' (1973) 32(1) Cambridge Law Journal 104.

${ }^{70}$ See Williams v Walker-Thomas Furniture 350 FR 2d 445 (1965) referred to by Richard J Hunter Jnr, 'Unconscionability Revisited: A Comparative Approach' (1992) North Dakota Law Review 144.

${ }^{71}$ (2004) 211 ALR 342, [54].The court said 'When an attempt is made to introduce the concept of sufficient notice into the field of signed contracts, there is a danger of subverting fundamental principle based on sound legal policy.' 